\title{
Selection of $\mathrm{C}_{\alpha}-\mathrm{H}^{\cdots} \mathrm{O}$ hydrogen bond
}

We used the following selection criteria: (1) The hydrogen bond must involve an oxygen atom from a side-chain, since we can not modify backbone atoms by mutation. Only six $\mathrm{C}_{\alpha}-\mathrm{H}^{\prime \prime} \mathrm{O}$ hydrogen bonds fit this criterion. (2) The hydrogen bond must occur between helices in the structure. Helices remain largely intact in the SDS unfolded state of bR so most intra-helical hydrogen bond would not be required to break upon unfolding ${ }^{1,2,3}$. (3) The hydrogen bond must be in the central hydrophobic region of the transmembrane helices where hydrogen bond strength should be greatest. (4) The side-chain can not be involved in other obvious inter-helical interactions that would confuse interpretation of the results. Only one of the possible hydrogen bonds satisfied all four criteria.

\begin{tabular}{|c|c|c|c|c|}
\hline $\begin{array}{l}\text { The interacting } \\
\text { atoms }\end{array}$ & $\begin{array}{c}\mathbf{C}_{\alpha}^{\cdots} \mathbf{O} \\
\text { Distance }(\AA) \\
(\text { ideal }=3.3 \AA)\end{array}$ & $\begin{array}{c}\theta\left(^{\circ}\right) \\
\text { (ideal }=180)\end{array}$ & $\begin{array}{c}\varphi\left(^{\mathbf{o}}\right) \\
\text { (ideal }=\mathbf{1 0 9})\end{array}$ & $\begin{array}{l}\text { Why was this hydrogen bond chosen } \\
\text { or not chosen? }\end{array}$ \\
\hline $\begin{array}{l}\text { Ala51-C }{ }_{\alpha}-\mathrm{H} \\
\text { Thr24-O } \gamma\end{array}$ & 3.4 & 1117 & 115 & $\begin{array}{l}\text { The chosen H-bond. Only other } \\
\text { interaction is an intra-helical hydrogen } \\
\text { bond that should remain intact in both } \\
\text { the folded and unfolded states. This } \\
\text { region of the protein remains helical in } \\
\text { SDS, but tertiary contacts are lost } \\
\end{array}$ \\
\hline $\begin{array}{l}\text { Trp86-C }-\mathrm{H} \\
\operatorname{Thr} 17-\mathrm{O} \gamma\end{array}$ & 3.4 & 149 & 160 & $\begin{array}{l}\text { An intra-helical H-bond that would not } \\
\text { necessarily be broken in upon unfolding }\end{array}$ \\
\hline $\begin{array}{l}\text { Met118-C }-\mathrm{H} \\
\text { Ser141-O } \gamma\end{array}$ & 3.6 & 117 & 87 & $\begin{array}{l}\text { Poor geometry and Ser141-O } \gamma \text { makes } \\
\text { another traditional and inter-helical H- } \\
\text { bond. }\end{array}$ \\
\hline $\begin{array}{l}\text { Glu166- } \mathrm{C}_{\alpha}-\mathrm{H} \\
\text { Ser169-O } \gamma\end{array}$ & 3.3 & 132 & 158 & $\begin{array}{l}\text { An intra-helical H-bond that would not } \\
\text { necessarily be broken upon unfolding. } \\
\text { Ser169-O } \gamma \text { makes several other } \\
\text { traditional and inter-helical H-bonds. }\end{array}$ \\
\hline $\begin{array}{l}\text { Met209- } \mathrm{C}_{\alpha}-\mathrm{H} \\
\text { Tyr57-OH }\end{array}$ & 3.1 & 144 & 128 & $\begin{array}{l}\text { Tyr57-OH is involved in a number of } \\
\text { other traditional and inter-helical H- } \\
\text { bonds. }\end{array}$ \\
\hline $\begin{array}{l}\text { Asp212- } \mathrm{C}_{\alpha}-\mathrm{H}, \\
\text { Tyr185-OH }\end{array}$ & 3.3 & 124 & 173 & $\begin{array}{l}\text { Tyr185-OH is involved in a number of } \\
\text { other traditional and inter-helical H- } \\
\text { bonds. }\end{array}$ \\
\hline
\end{tabular}

\section{Table of $\mathrm{C}_{\alpha}-\mathrm{H} \cdots \mathrm{O}$ hydrogen bonds involving side-chains in bR}

transmembrane helices. Hydrogen bond geometries taken from the structure $1 \mathrm{KME}^{5} . \theta$ is the $\mathrm{C}_{\alpha}-\mathrm{H}-\mathrm{O}$ angle and $\varphi$ is the $\mathrm{H}-\mathrm{O}-\mathrm{C}$ angle. 


\section{Methods}

All bacteriorhodopsin mutants were created and purified as described in Faham et. al., $2004^{6}$. The SDS unfolding experiments were performed as described by Faham et. al., 2004. All the mutants were crystallized using the bicelle method ${ }^{5}$. $4 \mu$ l of a $4: 1$

protein/bicelle solution of $40 \% \mathrm{w} / \mathrm{v}, 2.8: 1 \mathrm{DMPC} / \mathrm{CHAPSO}$ was mixed with $1.5 \mu 1$ of a well solution, and then allowed to equilibrate with well solution by vapor diffusion at $37^{\circ} \mathrm{C}$. T24S was crystallized using a well solution containing $2.0 \mathrm{M} \mathrm{NaH}_{2} \mathrm{PO}_{4} \mathrm{pH} 3.7$ and 0.048M hexanediol. The crystallization solution for T46S was $2.6 \mathrm{M} \mathrm{NaH}_{2} \mathrm{PO}_{4} \mathrm{pH} 3.7$ and $0.060 \mathrm{M}$ hexanediol. The well solution for $\mathrm{T} 24 \mathrm{~V}$ was $2.2 \mathrm{M} \mathrm{NaH}_{2} \mathrm{PO}_{4} \mathrm{pH} 3.7$ and $0.060 \mathrm{M}$ hexanediol, and the well solution for T24A was $2.5 \mathrm{M} \mathrm{NaH}_{2} \mathrm{PO}_{4} \mathrm{pH} 3.7$ and 0.060M hexanediol. Crystals were transferred to a cryoprotectant solution of $4.0 \mathrm{M}$ $\mathrm{NaH}_{2} \mathrm{PO}_{4} \mathrm{pH} 3.7$ prior to freezing under a stream of liquid nitrogen. Data collection was performed at the Advanced Light Source (ALS) Beamline 8.2.2 at the Berkeley National Laboratory. X-ray diffraction data was processed and scaled using the DENZO package ${ }^{7}$ and the structure was solved by molecular replacement using the 1 PY6 structure ${ }^{6}$ and refined using CNS with a twinning fraction of $0.50^{7,8} .5 \%$ of the reflections were withheld for the calculation of Rfree. The same reflections withheld in the wild-type refinement were used for both mutant refinements to eliminate bias. T24S (PDB code 1S51) was refined to an Rfactor of 21.2 and an Rfree of 27.2 at $2.0 \AA$ resolution, and T46S (PDB code 1S53) was refined to an Rfactor of 21.4 and an Rfree of 26.6 at $2.0 \AA$ resolution. T24A (PDB code 1S54) was refined to an Rfactor of 24.3 and an Rfree of 28.7 at 2.2 Å resolution, and T24V (PDB code 1S52) was refined to an Rfactor of 19.9 and an Rfree of 26.6 at $2.3 \AA$ resolution. 


\section{References}

(1) Faham, S.; Yang, D.; Bare, E.; Yohannan, S.; Whitelegge, J. P.; Bowie, J. U. J Mol Biol 2004, 335, 297-305.

(2) Pervushin, K. V.; Orekhov, V.; Popov, A. I.; Musina, L.; Arseniev, A. S. Eur J Biochem 1994, 219, 571-583.

(3) Booth, P. J.; Curran, A. R. Curr Opin Struct Biol 1999, 9, 115-121.

(4) Hunt, J. F.; Earnest, T. N.; Bousche, O.; Kalghatgi, K.; Reilly, K.;

Horvath, C.; Rothschild, K. J.; Engelman, D. M. Biochemistry 1997, 36, 15156-15176.

(5) Faham, S.; Bowie, J. U. J Mol Biol 2002, 316, 1-6.

(6) Faham, S., Yang, D., Bare, E., Yohannan, S. Whitelegge, J.P., Bowie, J.U. Journal of Molecular Biology 2003.

(7) Otwinowski, Z., Minor, W. Methods of Enzymology 1997, 276, 307-326.

(8) Brunger, A. T.; Adams, P. D.; Clore, G. M.; DeLano, W. L.; Gros, P.; Grosse-Kunstleve, R. W.; Jiang, J. S.; Kuszewski, J.; Nilges, M.; Pannu, N. S.; Read, R. J.; Rice, L. M.; Simonson, T.; Warren, G. L. Acta Crystallogr D Biol Crystallogr 1998, 54 ( Pt 5), 905-921. 